\title{
Public Health Implications of Waste Dump to Inhabitants in the Environment
}

\author{
Mbachu Ifeoma Adaora Chima \\ Department of Microbiology, Chukwuemeka Odumegwu Ojukwu University, Uli, Nigeria
}

Email address:

ifyadambachu@gmail.com

To cite this article:

Mbachu Ifeoma Adaora Chima. Public Health Implications of Waste Dump to Inhabitants in the Environment. Frontiers in Environmental Microbiology. Vol. 4, No. 2, 2018, pp. 41-44. doi: 10.11648/j.fem.20180402.11

Received: January 16, 2018; Accepted: February 11, 2018; Published: March 8, 2018

\begin{abstract}
Dump sites are naturally associated with foul odour which obviously is product of microbial activities. The bacterial agents responsible for this decomposition may be injurious to humans. In order to determine the genera of bacteria responsible, Petri dishes containing three different types of media, nutrient, MacConkey and blood agars were exposed for fifteen minutes, and incubated at $37^{\circ} \mathrm{C}$ for 24 hours. Organisms that grew were analyzed to determine if they are pathogens. Five plates of each media were exposed, and the mean of the colony counts were expressed as colony forming units per millitre (cfu/ml). Three different dump sites were studied, namely school waste dump (SWD), Village waste dump (VWD) and Market waste dump (MWD). Results of Petri dish exposure for 15 mins showed mean cfu/ml of 300, 250 and 300 on nutrient agar for SWD, VWD and MWD respectively. 100, 120 and 150 on MacConkey agar for SWD, VWD and MWD respectively then 20, 15 and 25 on blood agar for SWD, VWD and MWD respectively. Cultural characteristics of the isolates revealed diverse shapes, margins, colours and sizes. Phenotypic characterization showed the Grain reaction, catalase, coagulase, motility, indole, oxidase tests, glucose fermentation, capsule and spore tests results of the isolates. Isolates were tentatively identified to be Listeria spp, Streptococcus spp, Escherischia spp, Staphylococcus spp, Bacillus spp. Shigella spp and Micrococcus spp, by Bergey's manual of determinative bacteriology. Virulence test by haemolysis assay showed both Streptococcus spp and Listeria spp to be $\alpha$-haemolysis negative and $\beta$-haemolysis positive. Their zones of inhibition were 2-2.5 mm and 3.0-3.5 mm for Streptococcus spp, while Listeria spp was $1.5 \mathrm{~mm}$. Capsule stain was positive for Streptococcus spp and Escherischia spp. Spore stain was positive only for Bacilluis spp. These finds show that pathogenic bacteria are associated with waste dumps and therefore can be injurious to public health.
\end{abstract}

Keywords: Waste Dumps, Public Health Implication, Pathogens

\section{Introduction}

Waste dump sites are associated with a myriad of microorganisms, many of which undoubtedly are pathogenic to man, plants and animals. On the occasion of dry seasons, some of these organisms change to forms like spores, capsules etc. and are deposited on buildings and other objects where they stay and de-face such buildings when water is made available. Is it not possible that some of these organisms are responsible for diseases and sickness of inhabitants in the environment? Ebe, et al, [8] in their work on bacteria associated with domestic solid waste dump in Egbu, reported of isolating five genera of bacteria from the waste and that Kleibsiella spp. was most common organism present. Other bacteria they isolated were Staphylococcus qureus, Esherichia coli and Corynebacteria. Similarly, Obire, et al, [14] isolated these bacteria Arthrobacter spp, Micrococum spp, Proteus spp, Serratia spp, Streptococcus spp., Staphylococcus aureus Pseudomonas spp, Bacillus, Klebsiella and Escherichia coli. These isolates are causative agents of diseases, some could be detrimental. They also isolated fungi among which are Aspergillus, Fusarium, and so on. Other researchers like Williams and Hakam, [19] and Odoyemi, [15] have reported of the presence of organisms identified to be pathogens of man, animals and plants from such waste dumps.

It is of crucial importance to address this issue of waste dumping as the health problems arising from the act are unquantifiable. The possible organisms associated with the waste dumps need to be isolated, characterized and 
studied in order to determine their role to public health. The investigation should determine the presence of virulent factors e.g. presence of capsule, Acharya [1], formation of spores, Cogliati, et al, [6] and virulence, Granato et al [10], toxins, enzymes (Casadevall \& Profsk [4]),. These investigations will help to educate the public on issues of waste collection and control. Therefore the aim of this paper is to investigate the virulence properties of bacterial isolates from waste dump in a college neighborhood.

\section{Materials and Methods}

i. Sample Collection: Five plates for each of the three different media, nutrient agar, MacCoukey agar and blood agar, used were exposed for fifteen minutes according to (Menezes et al., [12]) on three waste dumps, (i) school waste dump (SWD) (ii) Village waste dump (VWDs) and (iii) Market waste dump (MWD). These are all in Uli, Ihiala Local Government Area, Anambra State, Nigeria. At end of the 15 minutes exposure, the Petri dishes were covered, sent to the laboratory and incubated at $37^{\circ} \mathrm{C}$ for $24 \mathrm{hrs}$. The media were prepared according to Cheeseborough [5].

ii. Isolation of Pure bacteria from the exposed Petri dishes. The pure cultures of the bacterial isolates were obtained by aseptically streaking representative colonies of different morphological types which appeared on the exposed plates onto freshly prepared nutrient agar plates, according to (Jahir and Syed, [11]) and were incubated at $37^{\circ} \mathrm{C}$ fir $24 \mathrm{hrs}$. Discrete colonies which developed were sub-cultured on nutrient agar slopes and incubated at $37^{\circ} \mathrm{C}$ for $24 \mathrm{hrs}$. These served as pure stock cultures for subsequent characterization and analytical tests.

iii. Characterization and identification of isolations: The isolates were characterized phenotypically by means of Gram stain, motility, catalase, coagulase, indole, oxidase, and glucose fermentation tests. They were also identified on the basis of their cultural and morphological characteristics in accordance to Cruickshank et al, [7].

\subsection{Analytical Tests}

Spore staining. Smears of the various bacterial isolates which have incubated for $48-72 \mathrm{hrs}$. as pure cultures were made by collecting the culture with a sterile wire loop placed on the center of a clean slide and dropped sterile water on the culture. It was made molten by gentling swelling the slide to mix the culture and water. It was air dried and heat fixed by passing it through Bunsen flame three times. Then it was flooded with Malachite green and heated on Bunsen burner for 3 minutes. After heating, the slide was rinsed with water and air dried before dropping the counter stain Safranin which lasted for 2 minutes and was rinsed off with gentle running water. After air drying, the slides were viewed under oil immersion using $100 \mathrm{x}$ objective. The spores appeared green on a pink background. This is according to Chessborough, [5]

Capsule Staining: This was done according to the method of Barrow et al., [3]. A loopful of the respective isolates was collected with sterile wire loops from the pure cultures which had incubated for $48-72 \mathrm{hrs}$. and placed on slides. This was followed by a drop of Indian ink placed next to the cultures on the same slide. Carefully cover slips were placed over the two drops so that they mixed together. After this, the slides with their contents were examined under the microscope and the observation recorded.

\subsection{Virulence Test}

A modified method of Noble and Vosti [13] was used to do this test. Blood agar plates were exposed to the waste dump for 15 minutes and incubated for $48 \mathrm{hr}$ at $37^{\circ} \mathrm{C}$. After the incubation, the plates were observed for the development of zones of homolysis. The developed zones of hemolysis were measured; the colour of the organisms noted and the nature of the hemolysis whether they are alph $(\alpha-)$ or beta $(\beta-)$ hemolysis.

\subsection{Statistical Analysis}

Results of enumeration of isolates were analyzed using the mean

\section{Results}

Table 1. Number of bacterial colonies on the different media after 15mins exposure to waste dumps and $37^{\circ} \mathrm{C}$ incubation.

\begin{tabular}{llll}
\hline Media & SWD & VWD & MWD \\
\hline Nutrient agar & $300^{\mathrm{a}} \mathrm{cfu}$ & $250^{\mathrm{a}} \mathrm{cfu}$ & $300^{\mathrm{a}} \mathrm{cfu}$ \\
MacConkey agar & $100^{\mathrm{a}} \mathrm{cfu}$ & $120^{\mathrm{a}} \mathrm{cfu}$ & $150^{\mathrm{a}} \mathrm{cfu}$ \\
Blood agar & $20^{\mathrm{a}} \mathrm{cfu}$ & $15^{\mathrm{a}} \mathrm{cfu}$ & $25^{\mathrm{a}} \mathrm{cfu}$ \\
\hline
\end{tabular}

Sample Sites

$\mathrm{a}$ is the mean of five plates.

Table 2. Cultural Characteristics of Isolates on the Three Different Media in School Waste Dump (SWD).

\begin{tabular}{|c|c|c|c|c|}
\hline Type of Media & Shape & Margin & Colour & Size \\
\hline \multicolumn{5}{|l|}{ Nutrient agar } \\
\hline Isolate 1 & Round & Entire & Dark Yellow & $1-2 \mathrm{~mm} .5$ \\
\hline Isolate 2 & Irregular & Obate & Creamy & $3-3.5 \mathrm{~mm}$ \\
\hline Isolate 3 & Irregular & Filamentous & Creamy & $0.5-1 \mathrm{~mm}$ \\
\hline Isolate 4 & Convex & Lobate & Light yellow & $1.5-2 \mathrm{~mm}$ \\
\hline \multicolumn{5}{|l|}{ MacConkey agar } \\
\hline Isolate 1 & Convex & Entire & Pink & $3.5-5 \mathrm{~mm}$ \\
\hline Isolate 2 & Irregular & Lobate & Pink & $2-3 \mathrm{~mm}$ \\
\hline Isolate 3 & Convex & Entire & Colourless & $2.3 \mathrm{~mm}$ \\
\hline \multicolumn{5}{|l|}{ Blood agar } \\
\hline Isolate 1 & Irregular & Entire & Light Yellow & $1-2 \mathrm{~mm}$ \\
\hline Isolate 2 & Round & Entire & Cream & $2.5-3.0 \mathrm{~mm}$ \\
\hline
\end{tabular}


Table 3. Cultural Characteristics of Isolates on the Three Different Media in Village Waste Dump (VWD).

\begin{tabular}{lllll}
\hline Type of Media & Shape & Margin & Colour & Size \\
\hline Nutrient agar & & & & $2-3 \mathrm{~mm}$ \\
Isolate 1 & Circular & Entire & Light Yellow & $3.5-5 \mathrm{~mm}$ \\
Isolate 2 & Irregular & Filamentous & Creamy & $0.5-1 \mathrm{~mm}$ \\
Isolate 3 & Circular & Entire & Creamy & $0.5-1 \mathrm{~mm}$ \\
Isolate 4 & Circular & Erose & & \\
Mac Conkey agar & & & Pink & $0.5-1 \mathrm{~mm}$ \\
Isolate 1 & Circular & Entire & Colourless & $1-1.5 \mathrm{~mm}$ \\
Isolate 2 & Round & Entire & Pink & $3-4 \mathrm{~mm}$ \\
Isolate 3 & Convex & Erose & Creamy & $2-2.5 \mathrm{~mm}$ \\
Blood agar & & Entire & Light Yellow & $1.5-2.0 \mathrm{~mm}$ \\
Isolate 1 & Circular & Entire & & \\
Isolate 2 & Round & & &
\end{tabular}

Table 4. Cultural Characteristics of bacterial Isolates emanating from VWD, on the Three Different Media.

\begin{tabular}{lllll}
\hline Media type & Shape & Margin & Colour & Size \\
\hline Nutrient agar & & & & $23.5-5 \mathrm{~mm}$ \\
Isolate 1 & Filamentous & Filiform & Creamy & $0.5-1 \mathrm{~mm}$ \\
Isolate 2 & Irregular & Lobate & Light yellow & $1-1.5 \mathrm{~mm}$ \\
Isolate 3 & Circular & Entire & Creamy & $3-4 \mathrm{~mm}$ \\
Isolate 4 & Irregular & Undulate & Colourless & $3-4 \mathrm{~mm}$ \\
MacConkey agar & & & & $1.5-2 \mathrm{~mm}$ \\
Isolate 1 & Circular & Entire & Pink & $3.5-5 \mathrm{~mm}$ \\
Isolate 2 & Irregular & Undulate & Colourless & $2-2.5 \mathrm{~mm}$ \\
Isolate 3 & Filamentous & Filiform & Colourless & $2-3 \mathrm{~mm}$ \\
Blood agar & Lobate & Light Yellow & \\
Isolate 1 & Irregular & Entire & & \\
Isolate 2 & Circular & & & \\
\hline
\end{tabular}

Table 5. Virulence status of the isolates by haemolysis assay.

\begin{tabular}{lllll}
\hline Medium & Organism & $\boldsymbol{\alpha}$-Haemolysis & $\boldsymbol{\beta}$-Haemolysis & Zone of Inhibition \\
\hline \multirow{3}{*}{ Blood agar } & Streptococcus spp & Negative & Positive & $2-2.5 \mathrm{~mm}$ \\
& Streptococcus spp & Negative & Positive & $3.0-3.5 \mathrm{~mm}$ \\
& Listeria spp & Negative & Positive & $1.5-2 \mathrm{~mm}$ \\
\hline
\end{tabular}

Table 6. Characterization and Identification of Isolates on nutrient, MacConkey and Blood agars.

\begin{tabular}{|c|c|c|c|c|c|c|c|c|c|c|c|}
\hline Isolate & $\begin{array}{l}\text { Gram } \\
\text { reaction }\end{array}$ & Shape & Catalase & Coagulase & Motility & Indole & Oxidase & $\begin{array}{l}\text { Spore } \\
\text { test }\end{array}$ & $\begin{array}{l}\text { Capsule } \\
\text { test }\end{array}$ & $\begin{array}{l}\text { Glucose } \\
\text { fermentation }\end{array}$ & Identification \\
\hline 1 & + & Rod & + & - & + & - & - & - & - & $\mathrm{A} / \mathrm{G}$ & Listeria spp. \\
\hline 2 & + & $\begin{array}{l}\text { Cocci } \\
\text { in chains }\end{array}$ & - & - & - & - & - & - & + & $\mathrm{A} / \mathrm{G}$ & Streptococcus spp. \\
\hline 3 & - & Rod & - & - & + & + & - & - & + & $\mathrm{A} / \mathrm{G}$ & Escherichia spp. \\
\hline 4 & + & $\begin{array}{l}\text { Cocci } \\
\text { in chains }\end{array}$ & + & + & - & - & - & - & - & A & Staphylococcus spp. \\
\hline 5 & + & Rod & + & - & - & - & - & + & - & A & Bacillus spp. \\
\hline 6 & - & Rod & + & - & - & - & - & - & - & A & Shigella spp. \\
\hline 7 & + & $\begin{array}{l}\text { Cocci } \\
\text { in chains }\end{array}$ & + & + & - & - & - & - & - & - & Micrococcus spp. \\
\hline
\end{tabular}

Key - Negative A-acid.

+ Positive G-gas.

\section{Discussion}

The characterization and identification of the isolates revealed that the following bacteria are resident in the waste dumps. Listeria spp., Bacillus spp., Streptococcus spp., Staphylococcus spp., Escherichia spp., Shigella spp. and Micrococcus spp. (Table 6). This is in agreement with Obire et al, [14]; Odeyemi, [15] and Ezechi et al, [9]. All of these bacterial isolates are pathogenic and are causative agents of some noted human diseases. Listeria spp. have been reported to cause diseases like sepsis, meningitis and listerosis in neonates and immune compromised patients (Al -Ghazali and Al-Azawi [2]). Bacillus spp. have also been reported to cause diseases like anthrax, eye infections and food poisoning (Shoeni and Wong, [16]). Streptococcus spp. have been implicated in bacterial endocarditis, urinary tract infections, ear infections, mouth infections, phanyhgitis, scarlet fever, wound infections, skin infections and rheumatic fever (Seng et al., [17]). Staphylococcus spp. are noted for 
causing diseases such as wound infections, food poisoning, abscesses, toxic shock and urinary tract infections. Escherichia spp. cause diseases that include gastroenteritis, meningitis, urinary tract infections, wound and intraabdominal infections.

Lastly, Shigella spp. have been shown to be responsible for these diseases, bacillary dysentery and gastroenteritis. The only isolated non-pathogenic bacteria was Micrococcus spp. The activities of these organisms result in economic consequences as the lead to reduction in food security, loss of drinking water supplies and loss of economic opportunity since they contaminate food and drinking water supplies as well. The result of the virulence assay showed positive $\beta$ haemolysis which implies complete lysis of the erythrocytes. This suggests the extent of danger such waste dumps pose to public health. The colony forming units $(\mathrm{cfu} / \mathrm{ml})$ of the organisms were $300 \mathrm{cfu} / \mathrm{ml}$ and Nutrient agar (Table 1), 100 $\mathrm{cfu} / \mathrm{ml}, 120 \mathrm{cfu} / \mathrm{ml}$ and $150 \mathrm{cfu} / \mathrm{ml}$ on MacConkey agar and $20 \mathrm{cfu} / \mathrm{ml} 15 \mathrm{cfu} / \mathrm{ml}$ and $30 \mathrm{cfu} / \mathrm{ml}$ on blood agar. This shows that the organisms in waste dumps have very high population densities so that its only by removing the waste dumps from neighborhood that their health problems can be reduced to a minimum. The result of the capsule and spore stains were positive for Escherichia spp and Bacillus spp (Table 5). This is a factor that makes it very possible for air to carry these organisms, a means to perpetuating their virulence actions.

\section{Conclusion}

Waste dumps are associated with bacteria, many of which are pathogenic to humans. A good number of them possess $\beta$-haemolysis and other virulent qualities like capsule and spore formation.

\section{Recommendation}

Waste dumps should not be in residential neighborhood, because they provide every conditions necessary for the living of these organisms.

\section{References}

[1] Acharya, T. (2013). Bacterial Capsule: Structure, Importance and examples of capsulated bacteria.https://microbeonline.com/bacterial-capsulestructure-and-importance-and-examples-o.

[2] Al-Ghazali, M. R. and Al-Azawi, S. K. (1986). Detection and enumeration of Listeria monocytogenes is a sewage treatment plant in Iraq. Journal of Applied Bacteriology 60 (3): 251254.

[3] Barrow, J. R., Osuna-Avila, P. and Reyes-Vera, I. (2004). Fungal endophytes intrinsically associated with micropropagated plants regenerated from native Boutelona eriopoda Torr. and Atriplex canescens (Pursh) Nutt. In vitro cellular and Developmental Biology-Plant 40: 608-612.

[4] Casadevall, A. and Pirofski, L. (2009). Virulence factors and their mechanisms of action: the view from a damage-response framework: Journal of water and health 7: 501-518.

[5] Cheesbrough, M. (2006). District laboratory practice in tropical countries. 2nd Edn. Cambridge University Press, Cambridge, UK. ISBN-13: 9781139449298.

[6] Cogliati, S., Costa, J. G., Ayala, F. R., Donato, V., and Grau, R. (2016). Bacterial spore and its relatives as agents of mass destruction. Journal of bioterrorism and biodefence. 7:141. Doi: $10.4172 / 2157.1000141$.

[7] Cruickshank, R., Duguid, J. P., Marmion, B. R. and swain, R. H. A. (1975). Medical Microbiology, 12th Ed., Living stone, London, New York, 812-825.

[8] Ebe, T. E; Mgbemena, I. C; Njoku-Tony, R. F. Pmupja. E. E., Anyanwu, J. and Edward, K. C. (2015) Bacteria associated with domestic solid waste dump in Egbu, Owerri North Local Government area in Imo State, Nigeria. Journal of environment and Earth Science. 5 (12): 73-76.

[9] Ezechi, E. H., Isa, M. H. and Kutty, S. R. M. (2015). Bacteria associated with domestic solid waste dump in Egbu, Owerri North local government area in Imo State, Nigeria. Journal of Environment and Earth Science 12 (5): 2224-3216.

[10] Granato, E. T., Harrison, Freya, Kiimmerli, R. and RossGillespie, A. (2016). When is a bacterial "Virulence factor" realy virulent? bioRxiv doi: http://dx.doi.org/ 10.1101/061317.

[11] Jahir, A. K. and Syed, H. A. R. (2011). Isolation and characterization of microorganism from oil contaminated sites. Advances in Applied Science Research 2 (3): 455-460.

[12] Menezes, E. A., Pereira, E. C., Trindade, P., Costa, M. M., Freire, C. C., Cavalcante, M. S. and Cunha, F. A. (2004). Airborne fungi isolated from Fortaleza city, state of Ceara, Brazil. Journal of the Institute of Tropical Medicine of Sao Paulo 46 (3): 133-137.

[13] Noble, R. C. and Vosti, K. L. (1971). Production of double zones of hemolysis by certain strains of hemolytic Streptococci of groups A, B, C and G on heart infusion agar. Journal of Applied Microbiology 22 (2): 171-176.

[14] Obire, O., Nwaubeta, O. and Adue, S. B. N. (2002). Microbial community of a waste dump site Journal of Applied Sciences and Environmental Management. 6 (1): 78-81.

[15] Odeyemi, A. T. (2012). Antibiogram status of bacterial isolates from air around dump site of Ekiti State destitute centre at Ilokun, Ado-Ekiti, Nigeria. Journal of Microbiology Research 2 (2): 12-18.

[16] Schoeni, J. L. and Wong, A. C. L. (2005). Bacillus cereus food poisoning and its toxins. Journal of Food Protection 68 (3): 630-648.

[17] Seng, P., Vernier, M., Gay, A., Pinelli, P. O., Legre, R. and Stein, A. (2016). Clinical features and outcome of bone and joint infections with streptococcal involvement: 5-year experience of interregional reference centres in the south of France. New Microbes and New Infections 12: 8-17.

[18] Tankeshwar, A. (2013). Bacterial capsule: Structure, Importance and examples of capsulated bacteria. Microbe online. https://microbeonline.com.

[19] Williams, J. O. and Hakam, K. (2016). Microorganisms associated with dump sites in Port Harcourt Metropolis, Nigeria. Journal of Ecology and the National Environment. 8 (12): 8-12. 